EETP Vol. 15, 2020, №. 4(58)

ISSN 1896-2327 / e-ISSN 2353-7787

DOI: $10.35765 /$ eetp.2020.1558.01

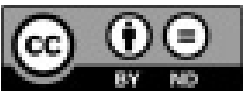

Nadesłano: 20.07 .2020

Zaakceptowano: 02.09.2020

Sugerowane cytowanie: Kos E. A. (2020). Wsparcie i modelowanie rozwoju dziecka w obszarze zdrowego odżywiania w rodzinie i placówce edukacyjnej, „Edukacja Elementarna w Teorii i Praktyce", vol. 15, nr 4(58), s. 9-22. DOI: 10.35765/eetp.2020.1558.01

\title{
Wsparcie i modelowanie rozwoju dziecka w obszarze zdrowego odżywiania w rodzinie i placówce edukacyjnej
}

\section{Supporting and Modeling Children's Development in the Area of Healthy Nutrition in the Family and in an Educational Institution}

\footnotetext{
SŁOWA KLUCZE ABSTRAKT

edukacja Celem opracowania jest zaakcentowanie potrzeby realizacji edukacji żywieniowa żywieniowej na wczesnym etapie rozwoju dzieci. Konieczność oddziaw przedszkolu ływań w tym zakresie jest bezsporna, wynika z wielu przesłanek teoi szkole, sensoryczne retycznych, a zwłaszcza praktycznych. Zamysłem pracy jest zwrócenie uczenie się uwagi na specyficzne potrzeby rozwojowe, które należy uwzględniać w edukacji projektując pracę z zakresu edukacji żywieniowej z najmłodszymi żywieniowej, dziećmi. techniki i formy pracy w edukacji żywieniowej, rozwój zainteresowań problematyką żywieniową, programy edukacji żywieniowej

Problemem, wokół którego koncentruje się niniejsza refleksja, jest pytanie, jak realizować działania związane z edukacją żywieniową wśród dzieci, a także jakie czynniki uwzględniać konstruując modele edukacji żywieniowej.

Analiza literatury źródłowej pozwala wskazać, że edukacja żywieniowa jest skutecznym narzędziem, które może być wykorzystywane $\mathrm{w}$ programach z zakresu promocji zdrowia już na etapie wczesnego dzieciństwa. Musi być realizowana za pośrednictwem odpowiednich technik, z uwzględnieniem specyficznych problemów, potrzeb rozwojowych dzieci. Powinna uwzględniać kontekst środowiskowy.
} 
W pierwszej części opracowania zdefiniowano pojęcie edukacji żywieniowej i usytuowano je na tle oddziaływań związanych z promocją zdrowia realizowaną w przedszkolu/ szkole. Następnie autorka podkreśla znaczenie środowiska edukacyjnego i rodzinnego w procesie budzenia zainteresowań związanych z problematyką żywieniową.

W dalszej części omawia możliwości kształtowania preferencji smakowych na wczesnym etapie życia i wsparcia rozwoju zdrowych praktyk związanych z żywieniem wśród dzieci. Charakteryzuje wybrane techniki realizacji edukacji żywieniowej w placówce edukacyjnej we współpracy z rodziną.

Na podstawie analizy literatury źródłowej można jednoznacznie wskazać potrzebę wdrażania działań z zakresu edukacji żywieniowej na pierwszych etapach kształcenia dziecka w celu wsparcia i modelowania procesu rozwoju zainteresowań problematyką żywieniową.

\section{KEYWORDS ABSTRACT}

nutrition education in kindergarten and school, sensory learning in nutrition education, techniques and forms of work in nutrition education, development of interest in nutrition issues, nutrition education programs
The aim of the study is to emphasize the need for nutritional education at an early stage of children's development. The necessity of influencing this field is indisputable. It results from many theoretical and especially practical premises. The idea of this article is to draw the readers' attention to specific developmental needs that should be considered when designing work in the field of nutrition education with the youngest children.

This reflection concentrates around the question concerning activities related to nutrition education among children and factors that must be taken into account in the construction of nutrition education models.

The analysis of source literature suggests that nutritional education is an effective tool that can be used in health promotion programs already in early childhood. Such education should be implemented using appropriate techniques, taking into account specific problems and developmental needs of children. It should also take into consideration the environmental context.

The first part of the study presents the definition of nutrition education and shows nutrition education against the background of activities related to health promotion implemented in kindergartens / schools. In the further part of the study, the author emphasizes the importance of the educational and family environment in the process of developing interests related to nutritional issues.

Next, the author presents the possibilities of influencing taste preferences at an early stage of life and supporting the development of healthy eating practices among children. The author characterizes 
selected techniques for the implementation of nutritional education in an educational institution in cooperation with the family.

On the basis of the analysis of source literature, we can indicate the need to implement activities in the field of nutrition education at the first stages of child education to support and model the process of developing interest in nutritional issues.

\section{Wprowadzenie}

Szeroko propagowane, zwłaszcza w ostatniej dekadzie, działania związane z edukacją żywieniową w społeczeństwie skutkują wzrostem świadomości żywieniowej i „pozytywnymi zmianami w zakresie nawyków żywieniowych Polaków (m.in. dostrzec można wzrost spożycia warzyw i owoców, tłuszczów roślinnych, ryb, a wraz z nimi witamin C, E i D; spadek spożycia mięsa czerwonego, tłuszczów zwierzęcych oraz soli)” (http://www.izz.waw.pl). Edukacja żywieniowa w społeczeństwie realizowana jest za pośrednictwem różnych podmiotów (media, liderzy opiniotwórczy, blogerzy kulinarni, organizacje konsumenckie) i kanałów przekazu informacji. Do popularnych technik upowszechniania wiedzy należą między innymi programy kulinarne (tego rodzaju programy zwiększają zainteresowanie tematyką zdrowego odżywiania, motywują do uważności w zakresie wyboru kupowanych produktów, np. zwracania uwagi na jakość, czytania składu etykiet, prezentują optymalne techniki kulinarne czy różnorodne typy produktów), artykuły, grafiki, filmy edukacyjne, rozmaite aplikacje mobilne, rodzinne warsztaty edukacyjno-kulinarne, szkolenia, handouty, diet coachingi.

Można stwierdzić, iż działania na rzecz poprawy sposobu żywienia i stanu odżywienia społeczeństwa przynoszą zamierzone skutki. Istotnym pytaniem pozostaje, w jaki sposób realizować działania związane z edukacją żywieniową wśród najmłodszych dzieci w wieku przedszkolnym, wczesnoszkolnym. Nikt nie odżywia się prawidłowo instynktownie. Tego trzeba się nauczyć, gdyż ludzie mają tendencje do wyboru produktów smacznych, tanich, znanych, łatwych w przygotowaniu.

Potrzeba realizacji edukacji żywieniowej wśród najmłodszych jest bezsporna i wynika z wielu przesłanek teoretycznych, a zwłaszcza praktycznych. Z punktu widzenia pedagogicznego istotnym jest namysł, jakie czynniki należy uwzględnić konstruując modele edukacji żywieniowej. Edukacja żywieniowa wśród najmłodszych musi być bowiem realizowana za pośrednictwem odpowiednich technik z uwzględnieniem specyficznych problemów (neofobia, wybiórczość pokarmowa, nadwrażliwość zmysłowa) i potrzeb rozwojowych dzieci oraz czynników motywacyjnych i uwzględniać kontekst środowiskowy. 
W niniejszym opracowaniu przedstawione zostaną odpowiedzi na postawione powyżej pytania. W pierwszej części omówione zostało pojęcie edukacji żywieniowej na tle oddziaływań związanych z promocją zdrowia w przedszkolu/szkole. Następnie podkreślone zostało znaczenie środowiska edukacyjnego i rodzinnego w procesie budzenia zainteresowań związanych z problematyką żywieniową i nabywania prawidłowych zachowań żywieniowych wśród dzieci i młodzieży. W dalszej części omówione zostały możliwości kształtowania preferencji żywieniowych na wczesnym etapie życia i wsparcia rozwoju zdrowych praktyk związanych z żywieniem wśród dzieci. W celu omówienia tychże możliwości przytoczone zostały wybrane techniki realizacji edukacji żywieniowej wśród najmłodszych dzieci w placówce edukacyjnej, we współpracy ze środowiskiem rodzinnym.

\section{Edukacja żywieniowa jako element programów promocji zdrowia realizowanych na terenie szkół i przedszkoli}

Na mocy Rozporządzenia Ministra Edukacji Narodowej z dnia 14 lutego 2017 r. w sprawie podstawy programowej wychowania przedszkolnego oraz podstawy programowej kształcenia ogólnego dla szkoły podstawowej placówki zobowiązane są do tworzenia sytuacji, które sprzyjają rozwojowi nawyków i zachowań prowadzących do dbania o zdrowie. Edukacja żywieniowa realizowana wśród dzieci i młodzieży jest integralnym, kluczowym elementem oddziaływań związanych z promocją zdrowia, a zwłaszcza kształtowaniem pożądanych postaw prozdrowotnych. Badania społeczne wskazują, że edukacja żywieniowa jest niezwykle skutecznym narzędziem, które może i powinno być wykorzystywane $\mathrm{w}$ programach z zakresu promocji zdrowia, które ogniskują swoje oddziaływanie na rozwoju zdrowych praktyk związanych z odżywianiem (Kelder, Perry, Klepo 1994).

Edukacja żywieniowa jest istotną częścią programu nauczania zarówno w przedszkolu, jak i szkole. Powinna być wdrażana już na wczesnym etapie rozwoju, gdyż odgrywa priorytetową rolę w promowaniu zdrowych nawyków żywieniowych przez całe życie jednostki. Wczesne dzieciństwo jest bowiem okresem intensywnego wzrostu i niezwykle istotnym czasem dla kształtowania się prawidłowych nawyków żywieniowych. Zachowania żywieniowe ukształtowane we wczesnych latach życia mają bowiem tendencję do utrzymywania się również w okresie dorosłości.

Realizacja edukacji żywieniowej wiąże się głównie z przekazywaniem dzieciom i młodzieży odpowiedniej wiedzy, która dostosowana powinna być do ich wieku. Już nawet najmłodsze dzieci wzbogacają swoją wiedzę o zdrowym żywieniu przez obserwację otaczającej je rzeczywistości, percepcję dostępnych obrazów, wzorów, przykładów. 
Kończąc przedszkole, zaczynają orientować się w zasadach zdrowego żywienia i zdrowego trybu życia (Kelder, Perry, Klepo 1994).

Działania z zakresu edukacji żywieniowej wśród najmłodszych dzieci, których często dotyczy problem neofobii i wybiórczości pokarmowej, koncentrują się zazwyczaj na dwóch priorytetach. Pierwszy odnosi się do modyfikacji postaw wobec odżywiania (ewentualnie kształtowania postaw, które sprzyjają zdrowemu funkcjonowaniu), zmiany nieprawidłowych wzorców konsumpcji lub nabywania nowych, akceptowanych z perspektywy celów edukacji żywieniowej. Drugi odnosi się do próby zwiększenia spożycia wybranych produktów, a zwłaszcza owoców i warzyw. W dalszej części niniejszego opracowania omówione zostaną wybrane metody i techniki, za pomocą których można powyższe cele realizować zarówno w środowisku przedszkolnym/ szkolnym, jak i rodzinnym. Warto jednak nadmienić, iż fundamentem dla realizacji wyżej wymienionych celi jest uprzednie wzbudzenie zainteresowania problematyką żywieniową.

\section{Znaczenie środowiska edukacyjnego i rodzinnego w procesie budzenia zainteresowań związanych z problematyka żywieniowa i nabywania prawidłowych zachowań żywieniowych}

Jak zostało wspomniane, wzbudzenie w podmiocie uczącym się zainteresowania wybraną problematyką jest fundamentem świadomego i zaangażowanego uczestnictwa w procesie uczenia się. W kontekście edukacji żywieniowej jest to szczególnie istotne, gdyż nie chodzi tu wyłącznie o transmisję określonego rodzaju wiedzy, lecz wywołanie względnie trwałych zmian postaw, zachowań ucznia, które mogą pojawić się na skutek zainteresowania wybraną tematyką.

Zgodnie z definicją Antoniny Guryckiej, zainteresowanie to „względnie trwała, obserwowalna dążność do poznawania otaczającego świata, przybierająca postać ukierunkowanej aktywności poznawczej o określonym nasileniu, przejawiająca się w selektywnym stosunku do otaczających zjawisk" (Gurycka 1998: 23-24)1. Zdaniem Wincentego Okonia zainteresowanie to „wyuczony składnik zachowania, nabywany w toku orientacyjno-badawczej aktywności dziecka” (Okoń 2001: 346). „Zainteresowania są utrwaloną, tj. pojawiającą się często i ukierunkowaną jednolicie ciekawością. Tak więc zaciekawienia stanowią podstawowy element struktury zainteresowań" (Gurycka 1989: 13).

Odwołuję się do definicji A. Guryckiej, która jest definicją globalną, co oznacza, iż obejmuje trzy aspekty zainteresowań: mobilizację uwagi, czynnik emocjonalny oraz orientację dynamiczną. 
Rozwój zainteresowań uwarunkowany jest oddziaływaniem czynników biogenetycznych (m.in. wiek, płeć, właściwości wrodzone - zdolności, predyspozycje, inteligencja) oraz społeczno-kulturowych (m.in. dom rodzinny, szkoła/przedszkole, środowisko rówieśnicze, środowisko geospołeczne - miasto, wieś) (Zawadzka 1995: 60). Właśnie z tego względu rola środowiska rodzinnego i instytucjonalnego, jakim jest przedszkole i szkoła, wydaje się być kluczowa w procesie rozwoju zainteresowania problematyką żywienia.

Edukacja żywieniowa odbywa się zwłaszcza w toku codziennych relacji w życiu rodzinnym już od pierwszych chwil po narodzinach. „W tym najwcześniejszym okresie życia dziecko w sposób naturalny dostosowuje się do środowiska, otoczenia, w którym żyje” (Surma 2012: 62), „nie uczy się, ale »inkarnuje« świat, wchłania go” (Surma 2012: 65). To właśnie w rodzinie modelowane są zwyczaje, a także zachowania żywieniowe jej członków. Dziecko nieustannie uczy się praktycznych umiejętności, które związane są z wyborem, przygotowaniem, spożyciem wybranych produktów. To przede wszystkim rodzice tworzą pozytywne lub negatywne wzorce $\mathrm{w}$ tym zakresie (Platta, Pukszta 2018). Jednak „dziecko uczy się (...) dzięki własnej aktywności, a rolą dorosłego jest stworzenie mu (...), odpowiednich warunków, w których będzie mogło rozwinąc cechy i kompetencje pomocne w dostosowywaniu się do zmieniającej się rzeczywistości" (Surma 2012: 25), to jest poznać prawidłowe zachowania żywieniowe, nabyć odpowiednie postawy i nawyki żywieniowe.

Rodzina stanowi pierwsze, podstawowe i najważniejsze źródło wiedzy z zakresu problematyki żywieniowej. Relacje osobowe, uczuciowe w rodzinie są zazwyczaj na tyle silne i trwałe, iż tworzą optymalne środowisko budzenia i kształtowania zainteresowań, a w ślad za tym postaw związanych z prawidłowym odżywianiem się, które mają szansę utrzymać się przez całe życie jednostki.

Placówka edukacyjna, jaką jest przedszkole czy szkoła, stanowi także bardzo ważne środowisko pedagogiczne, które oddziałuje na dziecko w sposób wielokierunkowy. Dzieci spędzają zwykle większą część dnia w przedszkolu, szkole. Istotnym jest zatem aby właśnie na ich terenie wdrożone zostały działania w zakresie edukacji żywieniowej, w tym korygowania złych nawyków żywieniowych, oraz zwiększania wiedzy na temat prawidłowego odżywiania (Platta, Pukszta 2018). Jest to istotne z tego względu, iż przedszkole/szkoła jako środowisko wspierające rodzinę w wychowaniu ma możliwość niwelować pewne jej zaniedbania w zakresie edukacji zdrowotnej, w tym również żywieniowej.

W przedszkolu dzieci mają szansę uczestniczyć w różnego rodzaju zajęciach, zabawach, które stanowić mogą idealną okazję do nabycia wiedzy o zdrowym odżywianiu, poznania i spróbowania po raz pierwszy nowych produktów, potraw (Nekitsing, Blundell-Birtill, Cockroft, Hetherington 2019). W szkole jest szansa na to, aby m.in. kształtować prawidłowe postawy żywieniowe, korygować te niekorzystne, przekazać 
wiedzę dotyczącą zasad żywienia, komponowania posiłków, wyboru i przechowywania żywności.

\section{Techniki wspierajace rozwój dziecka w obszarze zdrowego odżywiania w rodzinie i placówce edukacyjnej}

W tej części opracowania zaprezentowane zostaną wybrane techniki realizacji edukacji żywieniowej w placówce edukacyjnej, zwłaszcza wśród najmłodszych dzieci. Omówione zostaną te, które sprzyjają efektywnej ekspozycji (narażaniu) na nowy smak, jak i te związane z transmisją wiedzy na temat zdrowego odżywiania (m.in. omawianie podstawowych pojęć dotyczących żywności), związku pomiędzy odżywianiem się a zdrowiem (zwłaszcza konsekwencji zdrowotnych określonego sposobu odżywiania się). Akcent położony zostanie na techniki uczenia się sensorycznego, które mogą wykorzystać rodzice lub opiekunowie w pracy z dziećmi w wieku przedszkolnym, aby je zachęcić do poznawania nowych produktów czy smaków. Zasygnalizowane zostaną również sposoby uczenia się o zdrowym odżywianiu w środowisku rodzinnym.

Jak zostało wspomniane, placówki edukacyjne zobligowane są do kreowania sytuacji edukacyjnych, dzięki którym uczniowie mają możliwość zdobycia wiedzy i umiejętności związanych z prawidłowym odżywianiem. Edukacja żywieniowa w przedszkolu/szkole obejmować może działania z zakresu ekspozycji (narażenia) na smak oraz transmisji informacji na temat określonych produktów, zdrowych nawyków żywieniowych itd. Działania z tego zakresu realizowane są głównie za pomocą programów edukacji żywieniowej. Programy te są dostosowane do wieku dziecka, a poszczególne zadania powinny mieć walor edukacyjny, interaktywny i muszą być zabawne (Nekitsing, Blundell-Birtill, Hetherington 2019).

W Polsce realizowanych jest wiele programów z zakresu edukacji żywieniowej młodzieży, większość z ramienia Narodowego Centrum Edukacji Żywieniowej, jako zadania realizowane ze środków Narodowego Programu Zdrowia na lata 2016-2020 finansowanego przez Ministra Zdrowia. Programy typu: „Owoce i warzywa w szkole”, „Dobrze Jemy ze Szkołą na Widelcu”, „Jestem Ważny - Dbam o Siebie”, „Zdrowo Jemy, Zdrowo Rośniemy" stanowią skuteczne narzędzie kształtowania prawidłowych nawyków żywieniowych już u najmłodszych dzieci.

Wśród celów szczegółowych edukacji żywieniowej wymienić należy m.in.: przekazanie wiedzy o zasadach racjonalnego żywienia, kształtowanie postaw wobec różnych diet (np. wegetariańskiej, niskokalorycznej), kształtowanie umiejętności układania jadłospisu, przygotowywania potraw w sposób eliminujący utratę witamin, przechowywania produktów spożywczych, estetycznego nakrywania do stołu, tworzenie dobrej atmosfery przy spożywaniu posiłków (Posłuszna 2010). 
Warto nadmienić, iż oddziaływania związane z edukacją żywieniową powinny być wdrażane na najwcześniejszych etapach rozwoju dziecka. Mimi Tatlow-Golden, Eilis Hennessy, Moira Dean i Lynsey Hollywood (2013) wskazały, że dzieci w wieku 4 lat zaczynają już rozumieć związek między wzrostem, zdrowiem a odżywianiem, potrafią wskazać zdrowe i niezdrowe produkty, lecz mają trudność w rezygnowaniu z niezdrowych produktów. Isobel Contento i współautorzy (1995) także podali, że dzieci w wieku 3-5 lat potrafią rozpoznać żywność zdrową oraz niezdrową, rozumieją takie pojęcia jak składniki odżywcze, zawartość energetyczna itd.

Podstawowym sposobem przyswajania przez dzieci prawidłowych sposobów odżywiania jest uczenie się przez naśladownictwo w toku socjalizacji w życiu rodzinnym, i w szkole. Dzieci obserwując, chętnie naśladują zachowania rodziców, członków rodziny, nauczycieli, rówieśników. Stąd ważnym zaleceniem wydaje się być wspólne przygotowywanie oraz spożywanie posiłków w domu, ale i w szkole. Dziecko ma okazję poznać nowe produkty, które spożywa rodzic, czy nauczyciel, a nawet je spróbować bez odczuwania presji, przymusu. Dobrym pomysłem są także rozmowy na temat zdrowego odżywiania np. podczas nauki gotowania, czy spożywania posiłku.

W edukację żywieniową wpisują się także działania ukierunkowane na akceptację i zwiększenie spożycia określonych produktów (często nielubianych przez najmłodszych), np. mleka, kasz czy świeżych warzyw i owoców. Są to interwencje związane z uczeniem sensorycznym (sensor lessons). Techniki z tego obszaru zasadzają się na przekonaniu, iż chociażby jednorazowa ekspozycja smakowa lub wizualna nowego produktu może być wystarczająca, aby wytworzyć pozytywne nastawienie do niego (Zajonc 1968; Rioux, Lafraire, Picard 2018). Z kolei regularnie powtarzane działanie związane z ekspozycją na smak daje efekt w postaci akceptowania przez dziecko wybranego produktu w późniejszym czasie. Badania wykazały, że dzieci zwiększają spożycie wybranego produktu po pięciu tego rodzaju ekspozycjach; jednak zwykle dzieciom potrzeba od ośmiu do dziesięciu ekspozycji w regularnych odstępach czasu, np. raz w tygodniu (Hausner, Olsen, Moller 2012; Caton, Ahern, Remy, Nicklaus, Blundell, Hetherington 2013). Podobne wyniki uzyskano w wielu innych badaniach (Nekitsing, Blundell-Birtill, Cockroft, Hetherington 2019).

Skuteczność tego rodzaju interwencji podnosi nagradzanie dziecka po spróbowaniu chociażby małego kawałka nowego, bądź nielubianego produktu. Na podstawie badań eksplorujących kwestię związku nagrody i ekspozycji na smak stwierdzono, iż codzienne nagradzanie dziecka naklejką po zjedzeniu pojedynczego, małego kawałka nielubianych warzyw stało się wystarczające, aby docelowo zwiększyć spożycie wybranego warzywa (Cooke, Chambers, Añez, Croker, Boniface, Yeomans 2011; Fildes, Jaarsveld, Wardle, Cooke 2014). Okazuje się, iż łączenie ekspozycji na smak ze strategiami takimi jak nagradzanie i modelowanie ma długotrwałe skutki, nawet do 6 miesięcy 
po zakończeniu interwencji żywieniowej (Cooke, Chambers, Añez, Croker, Boniface, Yeomans 2011; Horne, Greenhalgh, Erjavec, Lowe, Viktor, Whitaker 2012).

Kolejną ze strategii wykorzystywaną w ramach edukacji żywieniowej może być interwencja związana z uczeniem wielosensorycznym. Ekspozycja na bodziec smakowy skojarzona zostaje z oddziaływaniem na zmysł wzroku, słuchu, dotyku oraz węchu. Należy zauważyć, iż mimo tego, że strategia narażenia na smak ma największy wpływ na promowanie spożycia wybranych produktów, to smak nie jest jedynym czynnikiem sensorycznym, na który narażone jest dziecko. W chwili, gdy dziecko poznaje smak określonego produktu zaangażowane są pozostałe systemy (modalności) sensoryczne - słuch (nazwa jedzenia, dźwięk wydawany podczas żucia), wzrok (postrzeganie wzrokowe produktu spożywczego), dotyk (percepcja tekstury w dłoniach/ konsystencji ustach) i zmysł węchu (dziecko czuje zapach żywności) (Dazeley, Houston-Price 2015: 1-6).

Współczesne badania wśród dzieci w wieku przedszkolnym sugerują, że działania w ramach edukacji żywieniowej powinny wiązać się z oddziaływaniem także na pozasmakowe modalności sensoryczne. Faktem jest, iż dominującym zmysłem, na który oddziałujemy w zakresie edukacji żywieniowej, jest smak. Warto jednak włączyć różne kanały oddziaływania (dotyk, węch, słuch, wzrok), aby zoptymalizować efekty interwencji żywieniowych, zwłaszcza wśród najmłodszych dzieci, które mają problem wybiórczości pokarmowej czy neofobii pokarmowej zwykle związanej z nadwrażliwością wybranych zmysłów.

Jedną z podstawowych i często stosowanych technik jest wizualna ekspozycja określonego produktu. Warto nadmienić, iż badania nad ekspozycją wizualną za pomocą tablic, książek z ilustracjami przyniosły mieszane wyniki pod względem ich skuteczności w zwiększaniu akceptacji wybranych produktów spożywczych.

Zaleca się również jak najczęstsze umożliwianie dzieciom spożywania wybranych posiłków, zwłaszcza uzupełniających, palcami, aby mogły poznać nowe tekstury wybranych produktów. Ekspozycja na zapach żywności także przyczynia się do ogólnego odczuwania smaku i może wpływać na chęć spożywania określonego produktu. Skutecznymi technikami wspierającymi okazują się również śpiewanie, rymowanie z dziećmi tekstów zawierających nazwy wybranych produktów (Dazeley, Houston-Price 2015).

Trzeba wspomnieć, że badania przeprowadzone wśród dzieci w wieku 12-36 miesięcy wykazały, iż zapoznawanie dzieci z nieznanymi owocami i warzywami z wykorzystaniem różnych modalności sensorycznych przez 4 tygodnie zwiększyło ich gotowość do dotykania i smakowania tych produktów (Dazeley, Houston-Price 2015). Do podobnych wniosków doszli H. Coulthard i A. Sealy, którzy twierdzą, że pojedyncza sesja zabawy polisensorycznej z owocami i warzywami wystarcza, aby zachęcić dzieci do ich spróbowania (Coulthard, Sealy 2017). 
Rys. 1. Podstawowe techniki uczenia się sensorycznego, które mogą wykorzystać rodzice lub opiekunowie w pracy z dziećmi w wieku przedszkolnym, aby je zachęcić do poznawania nowych produktów

\section{StUCH}

1. Słuchanie i powtarzanie nazw wybranych produktów spożywczych

2. Słuchanie opowiadań, piosenek, wierszyków o produktach spożywczych

3. Dotykanie produktów spożywczych i słuchanie, jaki dźwięk wydają

4. Słuchanie dźwięku gryzienia, żucia produktu

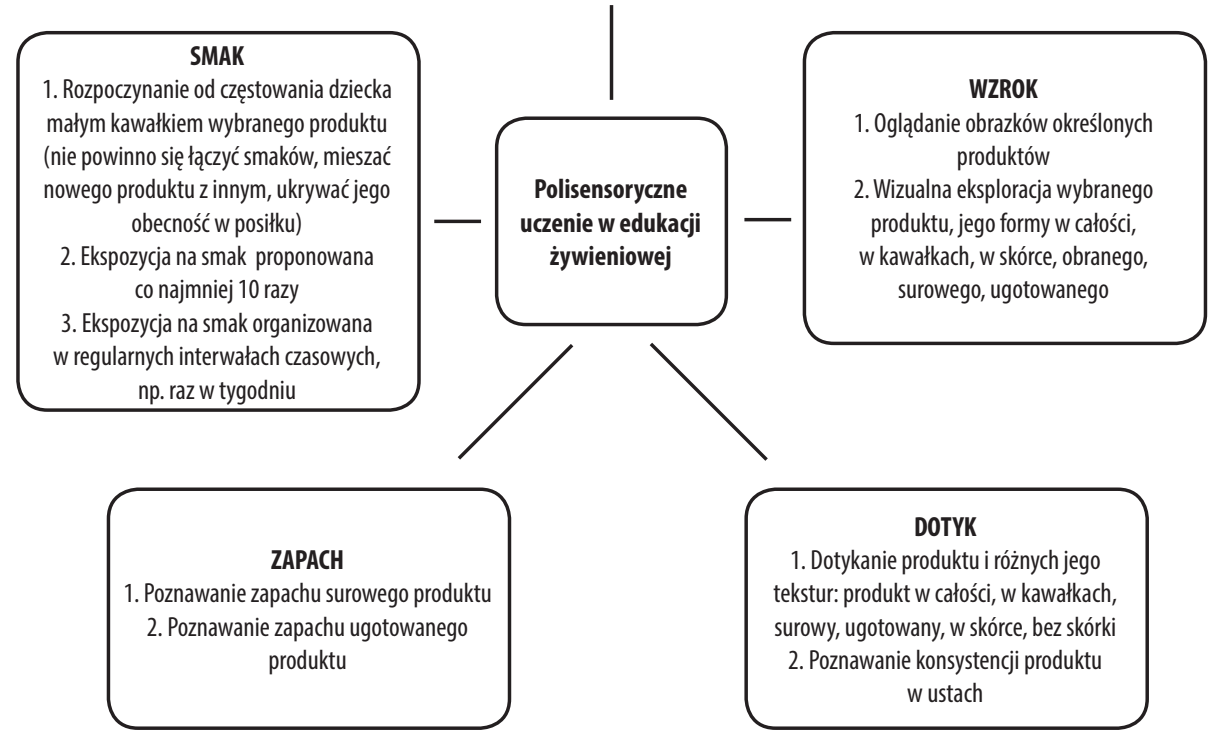

Źródło: (Dazeley, Houston-Price 2015: 1-6).

Omówione powyżej techniki mają na celu przede wszystkim zwiększenie spożycia określonych produktów spożywczych. Jak zostało jednak wspomniane, celem edukacji żywieniowej jest także transmisja wiedzy o zdrowym odżywianiu. W tym aspekcie nauczyciele, opiekunowie mogą stosować różne formy oddziaływania. Najpopularniejszymi formami są m.in.: pogadanki, zajęcia warsztatowe z wykorzystaniem metod aktywizujących, organizowanie spotkań z dietetykiem, konkursy plastyczne czy literackie. Trzeba nadmienić, iż realizację zajęć warto oprzeć na czterostopniowym modelu uczenia się przez doświadczenie ${ }^{2}$, stosując metody aktywizujące i interaktywne (Wolny 2013).

2 Edukacja oparta na doświadczeniu, uznawana za bardziej efektywną alternatywę dla tradycyjnych sposobów nauczania, uznaje różne style uczenia się. Popularnym schematem procesu uczenia się opartego na 
Warto również wspomnieć o edukacji rówieśniczej. Uczenie się poprzez obserwację zachowań żywieniowych rówieśników stało się obecnie popularną strategią interwencji promujących zdrowie wśród nastolatków. Strategia ta nie jest dotychczas szeroko stosowana w szkolnej edukacji żywieniowej w Polsce. Wyniki badań pokazują jednak, że oddziaływania w ramach edukacji żywieniowej realizowane przez rówieśników w szkołach są wykonalne i mają wysoki poziom akceptacji wśród liderów, uczniów i nauczycieli (Story, Lytle, Birnbaum 2002: 121-127).

Jak zostało wspomniane na początku niniejszego paragrafu, edukacja żywieniowa odbywa się nieustannie w toku codziennych relacji w życiu rodzinnym. Warto jednak wspomnieć, iż działania w tym obszarze realizowane w środowisku instytucjonalnym i rodzinnym powinny się wzajemnie dopełniać. $Z$ tego względu istotne wydaje się być włączenie rodziny $\mathrm{w}$ interwencję żywieniową proponowaną na terenie przedszkola lub szkoły. Skuteczność tego rodzaju działania potwierdzona została między innymi w badaniach S. Aktaç, G. Kızıltan, S. Avcı (Aktaç, Kızıltan, Avcı 2019).

Rodzice powinni być zaangażowani w realizowany program edukacyjny, gdyż to oni są przede wszystkim odpowiedzialni za kształtowanie prawidłowych zachowań i nawyków żywieniowych u swoich dzieci. Działania w ramach edukacji żywieniowej powinny być zorientowane tak, aby zainteresować rodziców tematyką prawidłowego żywienia. Istotne jest, aby pod wpływem programu przeznaczonego dla dzieci także opiekunowie poszerzyli swoją wiedzę i zmienili dotychczasowe zachowania żywieniowe.

Edukacja rodziców odbywać się więc może przede wszystkim poprzez materiały edukacyjne przekazywane dzieciom, zadania, które trzeba wykonać w domu wspólnie z opiekunami, szkolenia dotyczące aktualnych zaleceń żywienia dziecka, prelekcje, w toku których porusza się tematykę związku żywienia dziecka z rozwojem wybranych chorób cywilizacyjnych.

Warto nadmienić, iż jeżeli pod wpływem programu edukacyjnego opracowanego dla dzieci, zmianie ulegnie wiedza i zachowania żywieniowe ich rodziców, to prawdopodobieństwo, że zmiany te będą dotyczyć również dzieci i w ogóle całej rodziny, jest znacznie większe. Zatem poprzez edukację dzieci mamy możliwość edukowania ich rodziców. Można bowiem dostrzec zależność między otrzymanymi przez dzieci materiałami edukacyjnymi a zmianą wybranych zachowań żywieniowych i wzrostem poziomu wiedzy o żywieniu opiekunów (Kozłowska-Wojciechowska, Uramowska-Żyto, Jarosz, Makarewicz-Wujec 2002).

doświadczeniu jest model Kolba. Zgodnie z propozycją autora na proces uczenia się składają się cykle, z których każdy dzieli się na cztery etapy: doświadczenie, obserwację i refleksję, generalizację oraz zastosowanie (Manolis, Burns, Assudani, Chinta 2013: 44-52). 
Niedostateczny poziom wiedzy o konieczności prawidłowego odżywiania się, nieprawidłowe nawyki żywieniowe dzieci zwykle można przypisać niepełnym i nieprawidłowym nawykom żywieniowym ich rodzin. Wskutek oddziaływań z zakresu edukacji żywieniowej rodzice mogą skutecznie zmieniać własne postawy, zachowania i preferencje żywieniowe, zwiększyć poziom wiedzy na temat potrzeby zdrowego odżywiania, a w konsekwencji stać się wzorem do naśladowania dla dzieci (Aktaç, Kızıltan, Avc1 2019: 415-431).

\section{Podsumowanie}

Edukacja żywieniowa wobec dzieci musi być dostosowana do ich specyficznych potrzeb i umiejętności. Dzieci znajdują się bowiem na różnych etapach rozwoju poznawczego, emocjonalnego, społecznego. Na każdym z tych etapów mają inne potrzeby i umiejętności, ale również inaczej myślą o sobie i o otaczającej je rzeczywistości. Właśnie ten aspekt, istotny z pedagogicznego punktu widzenia, należy wziąć pod uwagę planując interwencję żywieniową bądź program edukacyjny. W pracy z najmłodszymi dziećmi niezbędne jest stwarzanie sytuacji umożliwiających powtarzanie doświadczeń opartych na zabawie i sprzyjających ekspozycji nowych, smacznych, zdrowych produktów. Starsze dzieci nabywają zdolność do przetwarzania coraz większej ilości informacji. W pracy z tą grupą wiekową coraz większą funkcję spełniają poznawcze procesy motywacyjne. Dzieci nabywają umiejętność ustalania celów i poznawczej samoregulacji. Edukacja żywieniowa starszych dzieci powinna zatem uwzględniać czynniki środowiskowe i emocjonalne oraz być oparta na uprzedniej identyfikacji czynników motywujących, tak aby stworzyć przestrzeń do samodzielnego praktykowania nabytych umiejętności, ustalania celów działania oraz poznawczej samoregulacji (Contento 2018: 682).

\section{Bibliografia}

Aktaç Ş., Kızıltan G., Avc1 S. (2019). The Effect of Family Participation in Nutrition Education Intervention on the Nutritional Status of Preschool Age Children, „Education and Science", nr 44 (199), s. 415-431, DOI: 10.15390/EB.2019.7819.

Cooke L., Chambers L., Añez E., Croker H., Boniface D, Yeomans M. (2011). Eating for Pleasure or Profit: the Effect of Incentives on Children's Enjoyment of Vegetables, „Psychological Science”, nr 22(2), s. 190-196, DOI: 10.1177/0956797610394662.

Contento I., Balch G., Bronner Y., Lytle L., Maloney S., Olson C., Swadener S. (1995). The Effectiveness of Nutrition Education and Implications for Nutrition Education Policy, Programs, and Research: A Review of Research, "Journal of Nutrition Education”, nr 27, s. 279-418. 
Contento I. (2018). Edukacja żywieniowa, tłum. O. Siara, Warszawa: Wydawnictwo Naukowe PWN.

Coulthard H, Sealy A. (2017). Play with Your Food! Sensory Play is Associated with Tasting of Fruits and Vegetables in Preschool Children, „Appetite”, nr 113, s. 84-90, DOI: 10.1016/j.appet.2017.02.003.

Dazeley P, Houston-Price C. (2015). Exposure to Foods'Non-taste Sensory Properties. A Nursery Intervention to Increase Children's Willingness to Try Fruit and Vegetables, „Appetite”, nr 84, s. 1-6, DOI: 10.1016/j.appet.2014.08.040.

Gurycka A., (1989). Rozwój i ksztattowanie zainteresowań, Warszawa: WSiP.

Hassanzadeh-Rostami Z., Mirshekari M., Ranjbaran H., Khosravi S., Faghih S. (2018). Effect of Game-Based Nutrition Education on Nutritional Knowledge of Preschool Children, „International Journal of Nutrition Sciences”, nr 3(1), s. 50-55.

Horne P., Greenhalgh J., Erjavec M., Lowe C., Viktor S., Whitaker C. (2011). Increasing Pre-school Children's Consumption of Fruit and Vegetables. A Modelling and Rewards Intervention, „Appetite”, nr 56(2). s. 375-385, DOI: 10.1016/j.appet.2010.11.146.

Kelder S., Perry C., Klepp K. , Lytle L. (1994). Longitudinal Tracking of Adolescent Smoking, Physical Activity, and Food Choice Behaviors, „American Journal of Public Health Association”, nr 84 (7), s. 1121-1126, DOI: 10.2105/AJPH.84.7.1121.

Kozłowska-Wojciechowska M., Uramowska-Żyto B., Jarosz A., Makarewicz-Wujec M. (2002). Wptyw edukacji żywieniowej dzieci w wieku szkolnym na wiedzę i zachowania żywieniowe ich rodziców, „Rocznik PZH”, nr 53(3), s. 253-258.

Manolis Ch., Burns D., Assudani R., Chinta R. (2013). Assessing Experiential Learning Styles: A Methodological Reconstruction and Validation of the Kolb Learning Style Inventory, „Learning and Individual Differences”, nr 23, s. 44-52, DOI: 10.1016/j. lindif.2012.10.009.

Nekitsing Ch., Blundell-Birtill P., Cockroft J., Hetherington M. (2019). Taste Exposure Increases Intake and Nutrition Education Increases Willingness to Try an Unfamiliar Vegetable in Preschool Children: A Cluster Randomized Trial, "Journal of the Academy of Nutrition and Dietetics", nr 119 (12), s. 2004 - 2013, DOI: 10.1016/j. jand.2019.05.012.

Story M., Lytle L., Birnbaum A., Perry Ch. (2002). Peer-Led, School-Based Nutrition Education for Young Adolescents: Feasibility and Process Evaluation of the TEENS Study, "Journal of School Health", nr 72(3), s. 121-127, DOI: 10.1111/j.1746-1561.2002. tb06529.x.

Tatlow-Golden M., Hennessy E., Dean M., Hollywood L. (2013). Big, Strong and Healthy'. Young Children's Identification of Food and Drink that contribute to Healthy Growth, „Appetite”, nr 71, s. 163-170, DOI: 10.1016/j.appet.2013.08.007.

Platta A., Pukszta T. (2018). Poziom zainteresowania problematyka żywieniowa wybranej grupy dzieci i mtodzieży w wieku 10-16 lat, Zeszyty Naukowe Akademii Morskiej w Gdyni, nr 104/2018, s. 83-90.

Posłuszna M. (2010). Edukacja zdrowotna we wspótczesnej szkole - program prozdrowotny, „Problemy Pielęgniarstwa”, nr 18(2), s. 226-231. 
Rioux C., Lafraire J., Picard D., (2018). Visual Exposure and Categorization Performance Positively Influence 3- to 6-year-old Children's Willingness to Taste Unfamiliar Vegetables, „Appetite”, nr 120, s. 32-42, DOI: 10.1016/j.appet.2017.08.016.

Okoń W. (2001). Nowy stownik pedagogiczny, Warszawa: Wydawnictwo Akademickie „Żak".

Surma B. (2012). Edukacja jezzykowa w koncepcji pedagogicznej Marii Montessori, „Edukacja Elementarna w Teorii i Praktyce", nr 23(1), s. 62-76.

Surma B. (2012). Teoretyczne zatożenia ksztattowania postawy twórczej dzieci w wieku przedszkolnym, „Edukacja Elementarna w Teorii i Praktyce”, nr 26(4), s. 13-28.

Wolny B. (2013). Szkolna edukacja żywieniowa a preferowane sposoby odżywiania uczniów, „Lubelski Rocznik Pedagogiczny”, nr 32, s. 181-201.

Zajonc R. B. (1968). Attitudinal effects of mere exposure, "Journal of Personality and Social Psychology", 9 (2, Pt.2), s. 1-27.

Zawadzka B. (1995). Wychowanie zdrowotne w szkole podstawowej, Kielce: Wyższa Szkoła Pedagogiczna im. Jana Kochanowskiego.

Rozporządzenie Ministra Edukacji Narodowej z dnia 14 lutego 2017 r. w sprawie podstawy programowej wychowania przedszkolnego oraz podstawy programowej kształcenia ogólnego dla szkoły podstawowej, w tym dla uczniów z niepełnosprawnością intelektualną w stopniu umiarkowanym lub znacznym, kształcenia ogólnego dla branżowej szkoły I stopnia, kształcenia ogólnego dla szkoły specjalnej przysposabiającej do pracy oraz kształcenia ogólnego dla szkoły policealnej, Dz.U. 2017 poz. 356

http://www.izz.waw.pl/strona-gowna/3-aktualnoci/aktualnoci/555-naukowcy-zmodyfikowali-zalecenia-dotyczace-zdrowego-zywienia (data dostępu: 03.02.2020)

\section{ADRES DO KORESPONDENCJI}

Ewa Arleta Kos

Uniwersytet Łódzki

e-mail: ewakoos@wp.pl 